Journal of Humanities, Social and Management Sciences (JHSMS)

eISSN: 2788-4791 (online)

https://doi.org/10.47264/idea.jhsms/2.2.11

Vol. 2, No. 2 (July-December 2021), 150-167

https://www.ideapublishers.org/index.php/jhsms

Research Article

\title{
Comparative study on the impact of individual and institutional ownership on firm performance: Evidence from Pakistan Stock Exchange
}

\author{
Muhammad Sadil Ali ${ }^{1}$ | Lubna Riaz ${ }^{1}$ | Wasif Anis*2-3
}

1. Department of Business Administration, Allama Iqbal Open University, Islamabad, Pakistan.

2. Department of Management Science, Women University Swabi, Swabi, Pakistan.

3. Institute of Management Studies, University of Peshawar, Peshawar, Pakistan.

Corresponding Author Email: wasifanis098@gmail.com

Received: September 9, 2021

Published: November 15, 2021

\begin{abstract}
The study aims to examine the relationship between individual ownership, institutional ownership and firm performance. Further it comparatively analyses the impact of both institutional and individual ownership on firm performance. For this purpose, data have been collected from 64 firms listed on Pakistan Stock Exchange (PSX) for the period of 10 years (2011 - 2020). Random effects model has been employed to test the research hypotheses. This study compares the effect of individual and institutional ownership on firm performance. Result of the study shows that both institutional and individual ownership significantly affect firm performance. However, the degree of the effect is different for both individual and institutional investors. The institutional ownership influences the firm performance twice than the individual investors influence the performance. The results also reveal that the firm performance is positively associated with the firm size while negatively related with the financial leverage. Findings of the study are important for shareholders, managers, academicians and decision makers. They can use information to frame investors' friendly policies and guide shareholders in taking right financial decisions.
\end{abstract}

Keywords: firm performance, institutional ownership, individual ownership, financial leverage, firm size, non-financial companies, random effects model.

\section{How to Cite:}

Ali, M. S., Riaz, L., \& Anis, W. (2021). Comparative study on the impact of individual and institutional ownership on firm performance: Evidence from Pakistan Stock Exchange. Journal of Humanities, Social and Management Sciences (JHSMS), 2(2), 150-167. https://doi.org/10.47264/idea.jhsms/2.2.11

Publisher's Note: IDEA PUBLISHERS (IDEA Publications Group) stands neutral regarding jurisdictional claims in the published maps and institutional affiliations.

Copyright: (C) 2021 The Author(s), published by IDEA PUBLISHERS (IDEA Publications Group).

Licensing: This is an Open Access article published under the Creative Commons AttributionNonCommercial 4.0 International License (http://creativecommons.org/licenses/by-nc/4.0/) 


\section{Introduction}

Financial performance of the organizations is a crucial concept in today's competitive economic environment and globalization; a complex phenomenon that represents an indispensable initiative to implement and monitor long term strategic plans. It is considered as a source of sustainable economic growth through which different firms can expend businesses, create value, bring innovations, generate employment opportunities and pay taxes, thereby improving the overall financial well-being and economic conditions (Van-Vu et al., 2018). Examining firm performance and its antecedents can provide insights understanding and knowledge to explore what drives the performance and offer valuable feedback to both business executives and policy makers. In the corporate world and financial environment, institutional investors and firm performance have gained critical attention (Abdullah et al., 2011) as institutional investors play considerable role in making firms financial and non-financial decisions (Ali \& Hashmi, 2018). Carefully designed strategic plans and financial decisions taken by the firm's management along with giving equal importance to the executives, management roles, governance and ownership structure may lead to enhance the financial performance of the firms.

The association of ownership structure and performance has been a great concern for the finance researchers. Recent studies revealed that ownership structure positively contributes and influences firm performance. For example, Le and Phan (2017) reported that ownership structure positively affects performance of different firms. Memon et al. (2012) documented a positive association between proprietorship organization and financial performance of firms. The relationship between ownership structure and firm performance is important for firms as changes in ownership pattern can directly and indirectly affect performance of different companies. According to Elyasiani and Jia (2010) more managerial ownership will lessen the performance of the organization because their activities will reflect their benefits and ways to increase their earnings which may lead to an increase in cost of capital and will also reduce diversification in the investment prospects. Phung and Mishra (2016) have reported a significant effect of ownership organization on firms' performance while Demsetz and Villalonga (2001) found particularly no significant evidence indicating ownership structure effect on the performance of different firms.

Literature has identified many determinants of ownership structure affecting firms' performance. Moreover, Lin and $\mathrm{Fu}$ (2017) stated that different institutional investors positively affect performance while concentrated ownership has an inverse impact on the performance of companies. In the hindrance sight, individual investors may also play significant role to bring positive change in the financial performance (Thanatawee, 2013). Cornett et al. (2007) found a significant relationship between operating cash-flows returns and institutional investors. A study by Fauzi and Locke (2012) showed that the executives, institutional investors and members of board committee have a significant association with performance of firms. While Sangeerthan (2021) reported that individual ownership positively affects firm performance. Moreover, Lee (2009) measured the firm's performance by rate of Return on Assets (ROA) and reported that with the increase in ownership concentration, firm's financial performance significantly improves, but the researcher found insignificant relationship of both foreign and institutional ownership with firm performance. The higher institutional holding in developed as well as developing economies is depicted from the fact that institutional owners are considered as the most effective management monitoring devices. 
Comparative study on the impact of individual and institutional ownership on firm ...

Therefore, with institutional investor's expertise to manage and oversee the investment activities and financial affairs, they play a superior role in improving the management decisions and its efficiency (Fazlzadeh et al., 2011; Kuo et al., 2020).

It is worthwhile to note that since the 1980s, many emerging countries opted for privatization and market liberalization. Miller et al. (2009) argued that individual or family ownership can fill the institutional holes and resolve management related issues of firms. Emerging markets are considered to have a lack of strong market factors like capital management, product, labour and institutional loopholes that may hinder economic exchanges (Luo \& Chung, 2005). More focus on long-term projections can lead individual businesses to form close ties with their employees, clients, business partners and suppliers, resulting in gaining more power and incentives than other firms, thus reducing the financial risks and institutional voids. Despite the advantages of individual or family ownership, they may be a poor alternative for the formal establishments; as their informal norms, weak institutions and legal protections may entrench and exploit the benefits of control, abuse institutional voids, obstruct the efficiency and efficacy of internal and external monitoring which may hinder the market for corporate control (GomezMejia et al., 2011; Luo \& Chung, 2013).

The prospective gains of institutional investors in emerging markets comprise of their propensity for actively observing with the potential to reduce the possibility of excessive executive compensation, overinvestment and also reducing the associated financial risks (Ferreira \& Matos, 2008). Furthermore, by effectively monitoring and motivating long term research and development activities (David et al., 2001). Institutional ownership is linked with improved financial performance, firm value and profitability (Thanatawee, 2013). Increase in firm's value and profitability is concurred with controlling the top management's unfavourable activities and taking appropriate decisions leading to favourable outcomes, whereas the individual ownership cannot monitor the managerial activities effectively due to their lack of potential in terms of exercising rights and ability (Kho et al., 2009). Although, besides major shareholders, individual shareholders can also influence activities of the organizations. A considerable number of shares owned by individuals affect decision making process as minority shareholders can establish their own pressure group to maintain and product interest. Moreover, in developing countries less protection has been observed for individual investors which gives little space to influence management decisions. Therefore, they create their own group to oversee management activities and firm performance.

The existing studies on the firm performance are from established and developed countries with little evidence of such relation in emerging countries; thus, posing a barrier to consolidating knowledge and research. Several studies have recently focused on different ownership arrangements and their effects on performance of firms. Abbas et al. (2013) studied concentrated ownership, Javid (2012) considered family ownership. Managerial ownership was considered by Khan et al. (2012), whereas the study by Shah and Hussain (2012) reflected ownership structure. On the other hand, Abdullah et al. (2011) considered more than one ownership structures. There is a considerable literature from developed countries on the association of firm performance and ownership structure; however, to the best of our knowledge no comprehensive study has investigated the effect of the individual ownership on the firm's performance in comparison with the institutional ownership especially in Pakistan which is a developing country having less developed corporate governance as compared to developed countries. 
In the context of Pakistan, most of the businesses are controlled by the meditation of one or the other dominant block such as managers, executives and institutional stakeholders, thus reporting highly inconsistent results (Javid, 2012; Javid \& Iqbal, 2008). It is important to identify better ownership pattern which the organizations should follow to avoid any ambiguity because it will affect shareholders wealth, investment opportunities and future value of firms in the stock market by enhancing the firm performance. In this connection, this study has been undertaken to examine the effect of ownership on performance by taking the most updated data of PSX listed firms. The current research adds to the existing literature by comparing the effects of Institutional and individual ownership on the performance of non-financial companies. The remainder of this paper is organized as: the part two describes the relevant literature review; the part three explains the methodology, sampling, data collection procedure and data analysis techniques, whereas the part four determines the results, study findings and discussions in the light of relevant literature. This study finally concludes with conclusion, and directions for future research.

\section{Literature review}

The association between the firms' ownership structure and its performance has been widely studied by various scholars, researchers and academicians. Mixed evidence has been found in the studies leading to the conclusion that the ownership variables exert different effect on the firm profitability and performance (Kapopoulos \& Lazaretou, 2007; Ducassy \& Montandrau, 2015; Sakawa \& Watanabel, 2020). In contrast, some studies have stated that it has inverse or insignificant effect on the firm performance (Lefort \& Urzúa, 2008; Belkhir, 2009), and still other studies predicted significant association between the firm performance and its ownership structure (Daily et al., 2003; Nuryanah \& Islam, 2011). Mainly the studies have been conducted to examine the effect of different corporate governance mechanisms and the ownership variables on firms' performance. Little literature available regarding role of individual investors in firm performance.

Finance literature offers three perspectives regarding effect of institutional ownership on performance of the firms. First perspective is monitoring view, Shleifer and Vishny (1997) stated that institutional ownership actively oversees, and institutional investors vigorously monitor company's activities to decrease agency conflict and access to similar information which increases profitability and performance of the firms. Second point of view is "passive monitoring view", here the institutional investors are only targeting the immediate gains through taking temporary advantage based on latest information (Kochhar \& David, 1996). They are focusing on short term objectives in order to achieve portfolio goals, instead of monitoring management and firm's activities (Elyasiani \& Jia, 2010). Therefore, weak association could be predicted between institutional ownership and firm performance (Duggal \& Millar, 1999).

Third prospective regarding the institutional investor is known as "exploitation" view. With this view the institutional investors may exploit small shareholders through coordination with management to oversee the organizations activities and only emphasis on their own benefits rather than focusing on the organization and the minority shareholders' interests. Therefore, there exists a considerable connection between the institutional investor and performance of the firm (Elyasiani \& Jia, 2010). It is thus, concluded that group of "active monitoring" institutional investors continuously oversee the firm's activities by reducing information 
Comparative study on the impact of individual and institutional ownership on firm ...

asymmetry and agency problems that leads towards improvement in firm performance. Therefore, such types of institutional investor are very important for growth and improvement of firm operations.

It was observed that more proportion of insider ownership may lead towards poor performance. Due to entrenchment between insider's managers and directors, they might exercise their powers that leads to accumulate wealth through exploitation of minority owners (Shleifer \& Vishny, 1986). Institutional investors can directly affect management activities and influence firm performance. It was particularly true in China where firms with state ownership and controlling shareholder were following the same steps (Bradford et al., 2013; Liu et al., 2014; Jiang \& Kim, 2015). Firm performance can be influenced by financial and non-financial factors as well as firm specific and other factor such as financial environment of country, economic conditions etc. Large part of the corporate finance literature focuses on firm specific factors that influence performance of the firms. Among those factors ownership variables are considered important for firm's profitability and performance. Different ownership variables such as institutional ownership, insider ownership, family ownership and individual ownership affect firm performance differently. Institutional ownership significantly affects firm's activities and overall performance. Institutional investors invest money on behalf of others as a result they have a delegated monitoring role that may push them in making an effort to minimize the risk. They avoid investing money in firms having asymmetry information and exercise more control over management than any other group of shareholders (Campbell \& Mínguez-Vera, 2008).

According to Anderson and Reeb (2003), family owned public companies often delegates executive and powerful management positions to their family members despite the disagreement from monitory shareholders. Further they argued that family members possibly show better understanding of business nature and stewardship in achieving targets of familyowned firm, they focus on training and development of their successors. Past researchers have shown mixed results regarding impact of family ownership on performance of the firms. For instance, Javid (2012) observed that family-owned firm with CEO being a family member has put positive effect on firm performance but in contrast it is argued that it has opposite impact on firm performance (Barth et al., 2005). In non-family firms, the CEO awards higher compensation to board of directors but proportion of compensation is significantly lower in family firms; this will lead towards better firm performance. Some earlier studies documented that mutual fund in China have contributed towards the increasing firm's performance (Yuan et al., 2008) thus having an impact over its financial decision through voting rights (Firth et al., 2010).

A mixed evidence has been documented in the literature about the association between institutional investors and performance of the firms. For instance, Bhattacharya and Graham (2009) reported that institutional ownership can positively affect firm performance. Duggal and Millar (1999) observed a positive association between ownership proportion of institutional investor and firm performance, while Chaganti and Damanapour (1991) documented insignificant relationship between institutional investors and performance of the firms. However, according to Seifert et al. (2005) this relationship is not consistent across different economies like United States, Western Countries, Japan and Germany. Moreover, Fauzi and Locke (2012) showed that different ownership variables and arrangements may exert different impact on firms' performance. 
Two groups of institutional investors exist in literature; one is called pressure resistant and the other pressure sensitive. Whereby, the institutional investors put force to create value maximization in firms. In most previous studies, institutional investors were considered as monolithic group and predicted that institutional ownership is not related with firm performance (Faccio \& Lasfer, 2000). It was also found that presence of the institutional ownership is leading towards increasing research and development expenditures. Moreover, individual ownership is more related with dividend policy of the firm which influences management activities and further affects the association of management policies and firm performance. Further it is also documented that individual ownership significantly affects firm performance in developing markets (Sangeerthana, 2021).

From above literature we can assume following hypotheses:

H1: Institutional ownership positively affects performance of Pakistani listed firms.

$\mathrm{H} 2$ : Individual ownership positively affects performance of Pakistani listed firms.

H3: Effects of institutional ownership on firm performance is stronger as compared to individual ownership in Pakistan.

\section{Research methodology}

This research aims to examine the relationship between the institutional ownership, individual ownership and performance of the firms. Furthermore, it provides comparison by analysing whether individual ownership exerts the same effects on the firm performance and profitability as institutional ownership do or impact differently. The nature of this study is quantitative as panel data have been used to compare effect of both individual and institutional on firm performance. Panel data techniques are chosen as it combines both time series and crosssectional data.

\subsection{Sampling and procedure for data collection}

Initially 100 companies have been selected from all firms listed on PSX. Nevertheless, after data scrutiny only 64 companies have been included for further analysis as only those companies have been included in the sample which satisfied study requirements. Furthermore, following criteria has been followed to select sample of the study.

- Financial firms have not been included in the sample.

- At least one company has been selected from each sector.

- Companies listed on PSX for 10 consecutive years from 2011 to 2020.

- Availability of firm's annual reports.

For the true representation, we have selected at least one company from each sector on the basis of larger market capitalization. We have collected 10 years data from 2011 to 2020 to conduct the study analysis. The data related to asset, equity and leverage have been collected from the Balance Sheet Analysis (BSA) publish by central bank i.e., the State Bank of Pakistan (SBP). The ownership structure data have been extracted from the annual financial reports of 64 companies. These financial reports are retrieved from the State Bank of Pakistan and Pakistan Stock Exchange (PSX) websites. 


\subsection{Measures}

\subsubsection{Measurement of firm performance}

There exist many proxies to measure firm performance which is Dependent Variable (DV) in this research study. Many studies employed Return on Asset (ROA) to measure firm performance while other used Return on Equity (ROE) and Tobin Q to calculate firm profitability and performance. Due to high correlation with profitability and data availability we relied on ROA proxy to estimate firm performance. Based on previous studies we can drive following formula to calculate ROA:

$$
\text { Return on Asset }=\frac{\text { Firms Net income at the year end }}{\text { Firms total asset at year end }}
$$

ROA tells us how much company is earning profit relative to its total asset. Every company exists to earn profit and profit shows the financial performance of that firm. If company earns more profit in relation to average total asset, then it means firm performance is high otherwise company is not performing well. In other words, high ROA depicts strong firm performance while low ROA reflects poor performance of a company.

\subsubsection{Measurement of institutional ownership}

Institutional ownership means number of shares own by different institutions at the end of financial year. This is the ratio of different ownership and total outstanding shares of a company. The common way to calculate institutional ownership is:

$$
\text { Institutional ownership }=\frac{(\text { Total shares owned by different institutions })}{(\text { Total number of outstanding shares of the company) }}
$$

Only common shares are considered to calculate true institutional ownership. Total number of common shares held by different institutions from total outstanding shares of a firm.

\subsubsection{Measurement of individual ownership}

Individual ownership means percentage of ownership held by individual person. This excludes family ownership, managerial ownership and group ownership. Only individual investors have been considered to calculate individual ownerships. It can be calculated as:

$$
\text { Individual ownership }=\frac{(\text { Number of shares held by individuals })}{(\text { Total number of outstanding shares })}
$$

Similar method has been applied to calculate individual ownership. It is the ratio of common shares held by individuals to the total number of common shares of a company.

\subsubsection{Control variables}

The literature related to financial performance and ownership structure suggest following variables other than ownership patterns that can impact financial performance. Literature 
identified firm size can also affects firm performance as firm profitability largely depend on firm size. For example, large firm's net income is much higher than small companies and their asset are also more in terms of value. Therefore, they need large sales to earn comparative profit while small and medium type firms do not need that much amount. Likewise, Doğan (2013) reported that firm size positively associated with profitability and firm performance. We used natural log of market capitalization of each company to measure firm size of each company as Dang et al. (2018) suggested that market capitalization is more useful than other indicators (e.g., total asset \& total sales) to measure firm size when investigation firm performance in relation with capital structure.

Leverage level of a company affects its financial performance. There exists a direct association between the firms leverage and performance of the firms. Accountings' ratio have been used to measure the firm leverage. For instance, Ibhagui and Olokoyo (2018) used debt to equity ratio to measure the leverage level of the firms while others calculated the leverage by using market value of equity to book value of debt as measure of financial debt. Due to low specific long-term debt in Pakistan, we considered all interest-bearing loans (exceeding 1 year) as total debt, and it is divided by market value of equity to calculate financial leverage of the firm.

\subsection{Model specification/research model}

By using panel data, we comparatively analysed impact of individual and institutional ownership on performance of firms. We ran regression to estimate significance level of relationship between variables. Following model reflects theoretical framework of the study:

Firm performance $=$ Intercept + Institutional ownership + Individual ownership + Control variables + Error term

When we include measurement proxies detail equation becomes:

$\mathrm{ROA}_{\mathrm{i}, \mathrm{t}}=\beta_{0}+\beta_{1} \operatorname{InsO}_{\mathrm{i}, \mathrm{t}}+\beta_{2}$ IndO $_{\mathrm{i}, \mathrm{t}}+\beta_{3}$ Leverage $_{\mathrm{i}, \mathrm{t}}+\beta_{4}$ Firm Size $_{\mathrm{i}, \mathrm{t}}+\varepsilon \mathrm{i}, \mathrm{t}$

Where,

$\mathrm{ROA}_{\mathrm{i}, \mathrm{t}}=$ Return on Asset at time $\mathrm{t}$ representing firm performance

$\beta_{0}=$ intercept

$\beta_{1}$ InsO $_{\mathrm{i}, \mathrm{t}}=$ Institutional ownership, the fraction of shares owned by institutions at the end of the year $t$ for the firm $\mathrm{i}$

$\beta_{2} \mathrm{IndO}_{\mathrm{i}, \mathrm{t}}=$ Individual ownership, shares owned by individual investors at the end of the year $\mathrm{t}$ for the firm $\mathrm{i}$

$\beta_{3} L E V_{i, t}=$ control variable Firm leverage

$\beta_{4} F S_{i, t}=$ control variable Firm Performance

$\varepsilon \mathrm{i}, \mathrm{t}=$ vetor of error term 
Comparative study on the impact of individual and institutional ownership on firm ...

Analyses have been conducted in two levels. In first stage, analysis is carried to check the significance level of predictors and Dependent Variable (DV) while controlling other potential variables that can influence firm performance. In the next stage, we investigated comparative effect of both individual and institutional ownership on firm performance.

\subsection{Model selection}

To examine the impact of institutional and individual ownership on firm performance, we arranged panel data and employed different diagnostic tests to check the variability of data and identify relevant model. First of all, we run unit root test to check the stationary of data as it is prerequisite to examine the nature of data. Then we run different tests to check the autocorrelation, multicollinearity and heteroscedasticity. The different tests show data is normal and we can apply relevant test e.g., common effects, fixed effects and random effects model to data. Further, two tests i.e., Likelihood and Hausman test have been employed to select best fit model among above mentioned three techniques. Both likelihood and Hausman test show random effects model is the best fit model in our case. Fixed effects model presumes that intercept and slop is constant for all cross sections while random effects model assumes intercept is not constant across different companies and predicts that individual specific effects are uncorrelated while fixed effects model supposed that individual specific effect are correlated with predictors.

Table-1: Operational definitions of variables and calculations

\begin{tabular}{|c|c|c|}
\hline Variables & Calculations/Formulas & Source \\
\hline \multirow{2}{*}{$\begin{array}{l}\text { Firm } \\
\text { Performance }\end{array}$} & Net income of firm $i$ at time $t$ & (Le \& Phan, 2017) \\
\hline & $R O A=\overline{\text { Average equity of firm } i \text { at time } t}$ & (Jiraporn \& Liu, 2008) \\
\hline \multirow{2}{*}{$\begin{array}{l}\text { Institutional } \\
\text { Ownership }\end{array}$} & \multirow{2}{*}{ Ins $O=\frac{\text { Total shares owned by institutions }}{\text { Total number of outstanding shares }}$} & \multirow[t]{2}{*}{ (Ali \& Hashmi, 2018) } \\
\hline & & \\
\hline Individual & \multirow{2}{*}{ IndO $=\frac{\text { No.of shares owned by Individuals }}{\text { Total No.of oustanding shares }}$} & \multirow[t]{2}{*}{ (Thanatawee, 2013) } \\
\hline Ownership & & \\
\hline Firm Leverage & \multirow{2}{*}{$F L=\frac{(\text { Debt }) \text { Interest bearing loans at time } t}{\text { Market value of equity at time } t}$} & \multirow[t]{2}{*}{ (Ibhagui \& Olokoyo, 2018) } \\
\hline & & \\
\hline Firm Size & $F S=$ Natural log of Market Capitalization at $t$ & (Dang et al., 2018) \\
\hline
\end{tabular}

Note: Proxies used to measure variables.

Table-1 shows calculations of different formulas along with relevant sources. Different calculations and proxies have been used to measure study variables.

\section{Results and discussion}

\subsection{Descriptive statistics}

Descriptive statistic shows the nature and behaviour of data. Below table presents descriptive statistics of study variables. Standard deviation depicts dispersion of values from mean and skewness shows whether data is positively or negatively skewed, whereas kurtosis explains whether the data is platykurtic or leptokurtic (tall or flat). 
Table-2: Descriptive statistics

\begin{tabular}{lccccc}
\hline & ROA & $\begin{array}{c}\text { Institutional } \\
\text { Ownership }\end{array}$ & $\begin{array}{c}\text { Individual } \\
\text { Ownership }\end{array}$ & Firm leverage & Firm size \\
\hline Mean & 0.079 & 0.503 & 0.049 & 0.246 & 21.21 \\
Median & 0.048 & 0.503 & 0.039 & 0.183 & 21.22 \\
Maximum & 0.377 & 0.549 & 0.259 & 0.871 & 25.03 \\
Minimum & 0.003 & 0.457 & 0.013 & 0.006 & 17.90 \\
Standard & 0.081 & 0.206 & 0.026 & 0.218 & 2.036 \\
Deviation & 1.797 & 0.265 & 2.223 & 1.825 & 0.003 \\
Skewness & 6.078 & 2.088 & 11.45 & 3.332 & 2.223 \\
Kurtoses & 640 & 640 & 640 & 640 & 640 \\
Total observations & &
\end{tabular}

Note: ROA= Return on Assets; due to unique characteristics managerial, state and foreign ownership not included in either ownership types; Total firms 64; time period 10 years (2011-2020); Firm size is natural $\log$ of market capitalization.

The table-2 shows the statistical behaviour of data for the period of 2011 to 2020 . The mean value is range from 0.0493 (Individual ownership) to 21.212 (Firm Size). The values of standard deviation is range from 0.0266 (Institutional ownership) to 2.0368 (Firm size). Skewness indicates that all values are positively skewed. In case of Kurtoses most of the values in the table shows the leptokurtic behaviour, which mean data is tall and have high tail. Furthermore, the average percentage for individual ownership is nearly 5\% while intuitional ownership is $50.3 \%$ which means institutional investors hold larger proportion as compared to individual investors.

\subsection{Correlation analysis}

Below table shows correlations between firm performance and predictors. Correlation test has been run to check the endogeneity and multicollinearity problem. When the correlation value is " 1 " then we can say about the existence of strong correlation in between the variables, when the value of correlation is " 0 " then there exist no association, when the value of correlation is negative then we say that the correlation is negative.

Table-3: Correlation matrix

\begin{tabular}{lccccc}
\hline & $\begin{array}{c}\text { Firm } \\
\text { Performance }\end{array}$ & $\begin{array}{c}\text { Institutional } \\
\text { Ownership }\end{array}$ & $\begin{array}{c}\text { Individual } \\
\text { Ownership }\end{array}$ & $\begin{array}{c}\text { Firm } \\
\text { Leverage }\end{array}$ & $\begin{array}{c}\text { Firm } \\
\text { Size }\end{array}$ \\
\hline 1. Firm Performance & 1 & & & & \\
2. Institutional Ownership & 0.124 & 1 & & & \\
3. Individual Ownership & 0.081 & -0.245 & 1 & & \\
4. Firm Leverage & -0.067 & 0.094 & -0.066 & 1 & \\
5. Firm Size & 0.104 & -0.033 & 0.063 & -0.082 & 1 \\
\hline
\end{tabular}

Note: Negative coefficients show negative correlation while positive values show positive association; higher values indicate strong association and low values are indicating weak correlation.

Table-3 indicates that there exists no problem of multicollinearity between explanatory variables. Values of all independent variables are well below the threshold limit of 0.80 . Results 
Comparative study on the impact of individual and institutional ownership on firm ...

indicate that institutional ownership positively correlated with firm size and negatively correlated with individual ownership, whereas financial leverage negatively associated with both individual ownership and firm size. Result also depicts a positive association between ownership by individuals and firm size. Moreover, firm performance negatively associated with leverage and positively correlated will other predicting variables.

\subsection{Likelihood ratio/ redundant fixed effects tests}

In order to select the appropriate model from common coefficient and fixed effects model we have run likelihood test in panel data. Table 4 shows results of Likelihood ratio/ Redundant Fixed Effects Tests.

Table-4: Likelihood ratio test

\begin{tabular}{lccc}
\hline Redundant Fixed Effects Tests & statistics & d.f. & $\mathrm{p}$ \\
\hline Cross section F & 4.3733 & $(9,626)$ & 0.0000 \\
Cross section Chi-square & 39.0260 & 9 & 0.0000 \\
\hline
\end{tabular}

Table-4 shows significant Chi square value is for Likelihood test, which imply that fixed effects is the more efficient model.

\subsection{Hausman test}

Hausman test has been run to select best fit model from fixed and random effects model. Below table depicts the results of Hausman test.

Table-5: Hausman test

\begin{tabular}{lccc}
\hline Hausman Test & Chi-Sq. Statistic & Chi-Sq. d.f. & Prob. \\
\hline Cross-section random & 2.55040 & 4 & 0.6356 \\
\hline
\end{tabular}

Table-5 shows insignificant probability value for Houseman test, which means random effects model is the best fit model.

\subsection{Multivariate regression analysis (random effects model)}

The table- 6 provides results regarding regression analysis. As discussed earlier random effects model has been selected to examine the association between dependent and predicting variables. The value of F-statistics (probability) shows that the model is correct, and the predicting variables significantly affect the firm performance in the cross sections. The ownership has a significant and positive with firm performance $(\mathrm{p}<.01)$. There also exists a positive and significant relationship between individual ownership and firm performance as $\mathrm{p}$ value is 0.0067 , which is less than 0.01 . Similarly, firm size positively related with firm performance whereas financial leverage negatively affects firm performance. Coefficients indicate that an increase of 1 point in institutional ownership leads to 0.62 points change in firm performance whereas 1 unit change in the individual ownership brings 0.31 points change in the firm performance, which demonstrate that both institutional and individual ownership positively influence performance of the firms. The intensity and degree of effect is different 
for both individual and institutional investors. The institutional ownership influences the firm performance twice as much as the individual investors do influence. Consistent with prior studies, increase in firm's value and profitability is concurred upon controlling the top management's unfavourable activities and taking appropriate decisions leading to favourable outcomes, whereas the individual ownership cannot monitor the managerial activities effectively due to their lack of potential in terms of exercising control and voting rights (Kho et al., 2009).

Table-6: Random effects model

\begin{tabular}{lcccc}
\hline Variable & Coefficient & Std. Error & t-statistics & $\mathrm{p}(\mathrm{sig})$ \\
\hline Intercept (C) & -0.3240 & 0.0864 & -3.7471 & 0.0002 \\
Institutional Ownership & 0.6275 & 0.1549 & 4.0508 & 0.0001 \\
Individual Ownership & 0.3195 & 0.1195 & 2.6726 & 0.0077 \\
Firm Leverage & -0.0303 & 0.0144 & -2.0962 & 0.0365 \\
Firm Size & 0.0037 & 0.0015 & 2.4382 & 0.0150 \\
R-Square & .04577 & & & \\
Adj. R-Square & .03976 & & & \\
(Prob.) F-Statistic & .00005 & & & \\
Observations & 640 & & & \\
\hline
\end{tabular}

Note: Presents the results for the panel data using random effects model; where DV is firm performance (ROA); $p$-value less than 0.01 means relationship is significant at $99 \%$ confidence interval; $p$-value $<.05$ indicates relationship is statistically significant at $95 \%$ confidence interval; firms 64 ; periods 10 ; observations $=640$.

Moreover, the coefficient and $\mathrm{p}$-value of firm size is positively significant $(\mathrm{P}<0.05)$. The $\mathrm{p}$ value of financial leverage is $0.036(\mathrm{P}<0.05)$ and coefficient is -0.0303 , which implies that 1 point change in financial leverage brings -0.030 units change (decreases) in the financial performance. Memon et al. (2012) also reported that financial leverage negatively affects firm performance. Based on the results, it is argued that the firm with a higher institutional ownership strongly influences firm performance and leads to superior outcomes. While the individual ownership significantly affects the firm performance but does not bring much change in the firm performance. The institutions having considerable ownership directly and indirectly affect the firm performance. It is belief that institutional investors consistently monitor performance and perform a role of watch dogs in any firm. Overall, the institutional investors and individual ownership affect performance of the firms even after controlling for other variables.

The study findings show that institutional ownership positively and significantly significant affect firm performance, thus accepting first hypothesis, which is in line with the findings of Lin and Fu (2017) who documented a positive and significant relationship between the level of firm performance and institutional ownership. Findings also reveal that individual ownership directly affects firm performance however, this effect is low as compared to institutional ownership, therefore second and third hypotheses also have been accepted. These findings are in consonance with the prior studies which were conducted in different countries and geographical settings (e.g. Bhattacharya \& Graham, 2009; Thanatawee, 2013). The 
Comparative study on the impact of individual and institutional ownership on firm ...

confirmation of the hypothesized relationships from the present study supports the conventional interpretation that the institutional shareholders can better improve the firm's value in the emerging markets.

\section{Conclusion}

The firms' ownership structure and its impact on performance have endured a source of great attention for the financial market analysts. Not only the idea of ownership dispersion and firm performance is continuously evolved in finance theory, but it has also been widely debated. The ownership structure must be taken into consideration to appropriately fulfil the business needs. Factors like equity division of the company and the identity of equity owners along with their ownership patterns may affect their performance levels. The main focus of this study was to explore the potential effect of ownership variables on performance of firms and to comparatively analyse the impact of institutional and individual ownership on the firm performance. The related financial data was retrieved from the annual reports of 64 selected firms listed on PSX for the time period of 2011 to 2020 (10 years). Moreover, panel data have been used to compare the effect of both individual and institutional ownership on performance of the firms. The model of the study was based on the ownership literature and tested with the help of multivariate regression analyses. The present study observed that ownership structure is taking a critical part in enhancing the firm's performance. The research analysis provides evidence regarding the role of ownership patterns in adding the value and provides a potential lens for better understanding the effect of different ownership structures to improve the firm's profitability. The results are in line with the findings of earlier studies which stated that the firm's performance is greatly affected by changes in the ownership and overall firms' ownership structure.

The results provide empirical support to the existing literature. Institutional as well as individual ownership are significant non-financial factors of performance as such factors can directly impact performance of the firms; thus, providing new insights to the association of different ownership arrangements and firm's performance in emerging countries. The findings show that institutional investors have a considerable role in operating the financial markets and firms. They have the know-how, resources and necessary skills to influence the firm's performance; whether institutions influence financial decisions or not is somewhat a function of their ownership in the company. The finding of this study reveals that the individual ownership also has an effect in determining the performance level of the firms. The overall tendency in the research findings is that there is a positive linkage among the firm's status, individual ownership and firm performance. The financial strategies based on commitments, trust and informal settlements also help the firms with individual ownership to overcome the institutional problems thus leading them to identify substantial opportunities and efficient allocation of its resources.

It is also worthwhile to mention that different ownership variable can affect performance of firms. Our findings showed that both individual and institutional ownership positively impact firm performance. Nevertheless, the intensity and degree of effect is different for both individual and institutional investors. Furthermore, a firm with higher institutional ownership strongly influences firm performance and leads to superior outcomes; whereas individual ownership significantly affects firm performance but does not bring much change in the performance of non-financial companies. The findings of the present study affirm that different 
ownership structures affect the firm's performance in Pakistan; hence, study of these factors can provide great insight into understanding the financial behaviour of the firms in Pakistan. This study will help firms to better understand the role of ownership structure and its impact on firm performance.

\subsection{Policy implications}

An optimal ownership structure is important for better performance of companies. This study has highlighted the significant contribution of different ownership types and suggests that institutional ownership should be enhanced as institutional investors consistently monitor performance and perform a role of watch dogs in organizations. It is also recommended that policy makers in Pakistan should develop appropriate governance rules and bring policy reforms to strengthen firm performance. This study will provide implications for the policy makers in improving the governance of corporate sector as it offers new insights into ownership and agency issues that may be unique to the Pakistani corporate environment. Moreover, protection of minority and individual investors are important for smooth functioning of firms. Findings of the study can help firms to increase their profitability and performance. This could be done by formulating such strategies that may enable the decision makers to take appropriate actions regarding corporate governance mechanisms in order to avoid any expropriation of minority shareholders' wealth.

\subsection{Limitations and directions for future research}

The limitations of this study offer potential avenues for future research studies in the field of corporate governance. Due to high correlation with profitability, we used only ROA to measure performance of the firms. Future studies may use more than one proxy e.g., Tubin Q ratio and ROE to check the difference in the pattern of results. Furthermore, the generalizability of the study is only limited to the developing countries having similar financial markets and economic conditions. This study collected data from 64 non-financial companies while the future studies are suggested to increase the study sample by including other companies. The impact of foreign ownership should also be tested with firm performance as firms with foreign ownership would get the advantage of technological advancement and managerial skills. The same model can be applied to specific sector to extend the knowledge on whether the difference in ownership pattern would affect the firm performance in particular industry.

\section{References}

Abbas, A., Naqvi, H. A., \& Mirza, H. H. (2013). Impact of large ownership on firm performance: A case of non financial listed companies of Pakistan. World Applied Sciences Journal, 21(8), 1141-1152. http://citeseerx.ist.psu.edu/viewdoc/download?doi=10.1.1.388.5011\&rep=rep1\&typ $\underline{\mathrm{e}=\mathrm{pdf}}$

Abdullah, F., Shah, A., Gohar, R., \& Iqbal, A. M. (2011). The effect of group and family ownership on firm performance: Empirical evidence from Pakistan. International Review of Business Research Papers, 7(4), 191-208. https://ssrn.com/abstract $=1907150$ 
Comparative study on the impact of individual and institutional ownership on firm ...

Ali, M. S., \& Hashmi, S. H. (2018). Impact of institutional ownership on stock liquidity: Evidence from Karachi Stock Exchange, Pakistan. Global Business Review, 19(4), 939-951. https://doi.org/10.1177\%2F0972150918772927

Anderson, R. C., \& Reeb, D. M. (2003). Founding-family ownership and firm performance: Evidence from the S\&P 500. The Journal of Finance, 58(3), 1301-1328. https://doi.org/10.1111/1540-6261.00567

Barth, E., Gulbrandsen, T., \& Schønea, P. (2005). Family ownership and productivity: The role of owner-management. Journal of Corporate Finance, 11(1-2), 107-127. https://doi.org/10.1016/j.jcorpfin.2004.02.001

Belkhir, M. (2009). Board of directors' size and performance in the banking industry. International Journal of Managerial Finance, 5(2), 201-221. https://doi.org/10.1108/17439130910947903

Bhattacharya, P. S., \& Graham, M. A. (2009). On institutional ownership and firm performance: A disaggregated view. Journal of Multinational Financial Management, 19(5), 370-394. https://doi.org/10.1016/j.mulfin.2009.07.004

Bradford, W., Chen, C., \& Zhu, S. (2013). Cash dividend policy, corporate pyramids, and ownership structure: Evidence from China. International Review of Economics \& Finance, 27, 445-464. https://doi.org/10.1016/j.iref.2013.01.003

Campbell, K., \& Mínguez-Vera, A. (2008). Gender diversity in the boardroom and firm financial performance. Journal of Business Ethics, 83(3), 435-451. https://link.springer.com/article/10.1007/s10551-007-9630-y

Chaganti, R., \& Damanpour, F. (1991). Institutional ownership, capital structure, and firm performance. Strategic Management Journal, 12(7), 479-491. https://doi.org/10.1002/smj.4250120702

Cornett, M. M., Marcus, A. J., Saunders, A., \& Tehranian, H. (2007). The impact of institutional ownership on corporate operating performance. Journal of Banking \& Finance, 31(6), 1771-1794. https://doi.org/10.1016/j.jbankfin.2006.08.006

Daily, C. M., Dalton, D. R., \& Cannella Jr, A. A. (2003). Corporate governance: Decades of dialogue and data. Academy of Management Review, 28(3), 371-382. https://journals.aom.org/doi/abs/10.5465/AMR.2003.10196703

Dang, C., Li, Z. F., \& Yang, C. (2018). Measuring firm size in empirical corporate finance. Journal of Banking \& Finance, $86, \quad 159-176$. https://doi.org/10.1016/j.jbankfin.2017.09.006

David, P., Hitt, M. A., \& Gimeno, J. (2001). The influence of activism by institutional investors on R\&D. Academy of Management Journal, 44(1), 144-157. https://journals.aom.org/doi/abs/10.5465/3069342

Demsetz, H., \& Villalonga, B. (2001). Ownership structure and corporate performance. Journal of Corporate Finance, 7(3), 209-233. https://doi.org/10.1016/S0929$\underline{1199(01) 00020-7}$

Doğan, M. (2013). Does firm size affect the firm profitability? Evidence from Turkey. Research Journal of Finance and Accounting, 4(4), 53-59. https://core.ac.uk/download/pdf/234629457.pdf

Ducassy, I., \& Montandrau, S. (2015). Corporate social performance, ownership structure, and corporate governance in France. Research in International Business and Finance, 34, 383-396. https://doi.org/10.1016/j.ribaf.2015.02.002

Duggal, R., \& Millar, J. A. (1999). Institutional ownership and firm performance: The case of bidder returns. Journal of Corporate Finance, 5(2), 103-117. https://doi.org/10.1016/S0929-1199(98)00018-2 
Elyasiani, E., \& Jia, J. (2010). Distribution of institutional ownership and corporate firm performance. Journal of Banking \& Finance, 34(3), 606-620. https://doi.org/10.1016/j.jbankfin.2009.08.018

Faccio, M., \& Lasfer, M. A. (2000). Do occupational pension funds monitor companies in which they hold large stakes? Journal of Corporate Finance, 6(1), 71-110. https://doi.org/10.1016/S0929-1199(99)00016-4

Fauzi, F., \& Locke, S. (2012). Board structure, ownership structure and firm performance: A study of New Zealand listed-firms. https://hdl.handle.net/10289/7793

Fazlzadeh, A., Hendi, A. T., \& Mahboubi, K. (2011). The examination of the effect of ownership structure on firm performance in listed firms of Tehran stock exchange based on the type of the industry. International Journal of Business and Management, 6(3), 249.

Ferreira, M. A., \& Matos, P. (2008). The colors of investors' money: The role of institutional investors around the world. Journal of Financial Economics, 88(3), 499-533. https://doi.org/10.1016/j.jfineco.2007.07.003

Firth, M., Lin, C., \& Zou, H. (2010). Friend or foe? The role of state and mutual fund ownership in the split share structure reform in China. Journal of Financial and Quantitative Analysis, 45(3), 685-706. https://doi.org/10.1017/S0022109010000190

Gomez-Mejia, L. R., Cruz, C., Berrone, P., \& De Castro, J. (2011). The bind that ties: Socioemotional wealth preservation in family firms. Academy of Management Annals, 5(1), 653-707. https://doi.org/10.5465/19416520.2011.593320

Ibhagui, O. W., \& Olokoyo, F. O. (2018). Leverage and firm performance: New evidence on the role of firm size. The North American Journal of Economics and Finance, 45, 5782. https://doi.org/10.1016/j.najef.2018.02.002

Javid, A. Y. (2012). Impact of Family Ownership Concentration on the Firm's Performance (Evidence from Pakistani Capital Market). Journal of Asian Business Strategy, 2(3), 63.https://www.proquest.com/openview/754d4167db54850e6cfb85b0882ce959/1?p q-origsite $=$ gscholar $\& \mathrm{cbl}=1846335$

Javid, A. Y., \& Iqbal, R. (2008). Ownership concentration, corporate governance and firm performance: Evidence from Pakistan. The Pakistan Development Review, 47(4-II), 643-659.

Jiang, F., \& Kim, K. A. (2015). Corporate governance in China: A modern perspective. Journal of Corporate Finance, 32, 190-216. https://doi.org/10.1016/i.jcorpfin.2014.10.010

Jiraporn, P., \& Liu, Y. (2008). Capital structure, staggered boards, and firm value. Financial Analysts Journal, 64(1), 49-60. https://doi.org/10.2469/faj.v64.n1.7

Kapopoulos, P., \& Lazaretou, S. (2007). Corporate ownership structure and firm performance: Evidence from Greek firms. Corporate Governance: An International Review, 15(2), 144-158. https://doi.org/10.1111/j.1467-8683.2007.00551.x

Khan, M. A., Ullah, R., \& Shah, N. (2012). A relationship between insider's ownership and firm value: A case of Pakistani companies. https://papers.ssrn.com/sol3/papers.cfm?abstract id=2127100

Kho, B. C., Stulz, R. M., \& Warnock, F. E. (2009). Financial globalization, governance, and the evolution of the home bias. Journal of Accounting Research, 47(2), 597-635. https://doi.org/10.1111/j.1475-679X.2009.00323.X

Kochhar, R., \& David, P. (1996). Institutional investors and firm innovation: A test of competing hypotheses. Strategic Management Journal, 17(1), 73-84. https://doi.org/10.1002/(SICI)1097-0266(199601)17:1\%3C73::AID$\underline{\mathrm{SMJ} 795 \% 3 \mathrm{E} 3.0 . \mathrm{CO} ; 2-\mathrm{N}}$ 
Comparative study on the impact of individual and institutional ownership on firm ...

Kuo, K. C., Lu, W. M., \& Dinh, T. N. (2020). Firm performance and ownership structure: Dynamic network data envelopment analysis approach. Managerial and Decision Economics, 41(4), 608-623. https://doi.org/10.1002/mde.3124

Le, T. P. V., \& Phan, T. B. N. (2017). Capital structure and firm performance: Empirical evidence from a small transition country. Research in International Business and Finance, 42, 710-726. https://doi.org/10.1016/j.ribaf.2017.07.012

Lee, J. (2009). Does size matter in firm performance? Evidence from US public firms. International Journal of the Economics of Business, 16(2), 189-203. https://doi.org/10.1080/13571510902917400

Lefort, F., \& Urzúa, F. (2008). Board independence, firm performance and ownership concentration: Evidence from Chile. Journal of Business Research, 61(6), 615-622. https://doi.org/10.1016/j.jbusres.2007.06.036

Lin, Y. R., \& Fu, X. M. (2017). Does institutional ownership influence firm performance? Evidence from China. International Review of Economics \& Finance, 49, 17-57. https://doi.org/10.1016/j.iref.2017.01.021

Liu, C., Uchida, K., \& Yang, Y. (2014). Controlling shareholder, split-share structure reform and cash dividend payments in China. International Review of Economics \& Finance, 29, 339-357. https://doi.org/10.1016/j.iref.2013.06.008

Luo, X., \& Chung, C. N. (2005). Keeping it all in the family: The role of particularistic relationships in business group performance during institutional transition. Administrative Science Quarterly, 50(3), 404-439. https://doi.org/10.2189\%2Fasqu.2005.50.3.404

Luo, X. R., \& Chung, C.-N. (2013). Filling or abusing the institutional void? Ownership and management control of public family businesses in an emerging market. Organization Science, 24(2), 591-613. https://doi.org/10.1287/orsc.1120.0751

Memon, F., Bhutto, N. A., \& Abbas, G. (2012). Capital structure and firm performance: A case of textile sector of Pakistan. Asian Journal of Business and Management Sciences, $1(9), 9-15$.

Miller, D., Lee, J., Chang, S., \& Le Breton-Miller, I. (2009). Filling the institutional void: The social behavior and performance of family vs non-family technology firms in emerging markets. Journal of International Business Studies, 40(5), 802-817. https://www.elgaronline.com/view/edcoll/9781848443228/9781848443228.00009.x $\underline{\mathrm{ml}}$

Nuryanah, S., \& Islam, S. (2011). Corporate governance and performance: Evidence from an emerging market. Malaysian Accounting Review, 10(1). 17-42. http://dx.doi.org/10.24191/mar.v10i1.231

Phung, D. N., \& Mishra, A. V. (2016). Ownership structure and firm performance: Evidence from Vietnamese listed firms. Australian Economic Papers, 55(1), 63-98. https://doi.org/10.1111/1467-8454.12056

Sakawa, H., \& Watanabel, N. (2020). Institutional ownership and firm performance under stakeholder-oriented corporate governance. Sustainability, 12(3), 1021. https://doi.org/10.3390/su12031021

Sangeerthana, P. (2021). The impact of ownership structure on firm performance of listed manufacturing companies in $\quad$ Srilanka. http://repo.lib.jfn.ac.lk/ujrr/bitstream/123456789/3332/1/THE\%20IMPACT\%20OF \%200WNERSHIP\%20STRUCTURE\%200N\%20FIRM.pdf

Seifert, B., Gonenc, H., \& Wright, J. (2005). The international evidence on performance and equity ownership by insiders, blockholders, and institutions. Journal of Multinational 
Financial Management,
https://doi.org/10.1016/j.mulfin.2004.08.003

$171-191$.

Shah, S. Z. A., \& Hussain, Z. (2012). Impact of ownership structure on firm performance evidence from non-financial listed companies at Karachi Stock Exchange. International Research Journal of Finance and Economics, 84, 6-13.

Shleifer, A., \& Vishny, R. W. (1986). Large shareholders and corporate control. Journal of Political Economy, 94(3,

Part

$1)$ 461-488. https://www.journals.uchicago.edu/doi/abs/10.1086/261385

Shleifer, A., \& Vishny, R. W. (1997). A survey of corporate governance. The Journal of Finance, 52(2), 737-783. https://doi.org/10.1111/j.1540-6261.1997.tb04820.x

Thanatawee, Y. (2013). Ownership structure and dividend policy: Evidence from Thailand. International Journal of Economics and Finance, 5(1), 121-132. https://papers.ssrn.com/sol3/papers.cfm?abstract_id=2138186

Van Vu, H., Tran, T. Q., Van Nguyen, T., \& Lim, S. (2018). Corruption, types of corruption and firm financial performance: New evidence from a transitional economy. Journal of Business Ethics, 148(4), 847-858. https://link.springer.com/article/10.1007/s10551-016-3016-y

Yuan, R., Xiao, J. Z., \& Zou, H. (2008). Mutual funds' ownership and firm performance: Evidence from China. Journal of Banking \& Finance, 32(8), 1552-1565. https://doi.org/10.1016/j.jbankfin.2007.08.001 